\title{
PARENTAL INVOLVEMENT IN EDUCATION AMONG URBAN FAMILIES IN MALAYSIA
}

\author{
NurulHuda Mohd. Satar, ${ }^{* 1}$ Roza Hazli Zakaria, ${ }^{1}$ Nur Annizah Ishak**2 \\ *First author \\ ${ }^{* *}$ Corresponding author \\ ${ }^{1}$ Department of Economics, Faculty of Economics and Administration, University \\ of Malaya \\ ${ }^{2}$ Department of Development Studies, Faculty of Economics and Administration, \\ University of Malaya \\ (nurulhuda@um.edu.my, roza@um.edu.my, annizah@um.edu.my) \\ DOI: https://doi.org/10.22452/jati.vol25no2.4
}

\begin{abstract}
Parental involvement is one of the determinants of students' academic achievement. However, low parental involvement has been identified as one of the deterrence to improve the quality of education in Malaysia. This paper aimed to investigate this issue by examining the determinants of parental involvement at home among urban households with primary school-aged children. Using 744 self-reported data collected through a survey on households in Klang Valley, Malaysia, a score of home-based involvement was constructed. The estimation of the home-based involvement score against socio-economic characteristics of households suggested that families with younger and married parents involved favourably more in their children's education as compared to older and singleparent households. On the other hand, households with both parents working involved less in their children's education. However, at the same time, the involvement was found to be influenced positively by household income. As dual-earner families received larger income, this might offset the negative effect of dual-earner characteristic on involvement. The interaction between income and dual-earner variables revealed that the effect of income was canceled out when both parents are working, and they were from higher income group. In the case of middle-income group however, the higher income due to dual earnings did not compensate the lower commitment devoted to their children's education, which led to a negative total effect. These findings suggested a dilemma faced by the urban families, especially those of middle income.
\end{abstract}

Keywords: parental involvement, dual-earner families, middle-income households, Malaysia 


\section{Introduction and Background}

Education has long been recognised as an important source of economic growth. Two third of Gross Domestic Product (GDP) growth is explained by cognitive skills of the population (Hanushek, Weissman, Jamison, \& Jamison, 2008). The empirical evidences of positive contribution of education on the economy were also supported by McMahon (1998), Asteriou and Agiomirgianakis (2001), Petrakis and Stamatakis (2002), Self and Grabowski (2003; 2004), Lin (2003; 2004), Dickens, Sawmill and Tebbs (2006), The International Institute for Applied Systems Analysis (IIASA) (2008), Aghion, Boustan, Hoxby, and Vandenbussche (2009), Barro (2013), Pegkas (2014), and Liao, Du, Wang, and Yu (2019) among others. Education is also an essential mechanism to eradicate poverty as the probability of escaping poverty is associated with an increase in education (Patel, 2014).

According to a survey by the Ministry of Education Malaysia (MOE) in 2011, on average, a typical Malaysian student spends $52 \%$ of his or her time daily at home and with the community, and another 15\% at school. As children spend most of their time at home and school, these institutions are deemed very influential on students' performance. Thus, it is important for parents and teachers to cooperate to ensure that the children get the best education that will consequently shape their future. Past studies have called the idea of interaction and cooperation between parents, children, and teachers in the children's academic matters as parental involvement. Parental involvement in children's education can take place at home and at school. School-based parental involvement may include parent-teacher interaction about children's academic performance and parents' involvement in school-related activities. On the other hand, parental involvement at home includes their direct involvement in children's learning activities such as reading and helping with homework, and indirect involvement through anticipating and planning the homework (Wingard \& Forsberg, 2009).

There are numerous evidences on the positive effects of parental involvement on children. The most discussed positive effect was on students' academic achievement (White, 1982; Astone \& McLanahan, 1991; Ho \& Willms, 1996; Hill et al., 2004; Malecki \& Demaray, 2006; Stylianides \& Stylianides, 2011; Jeynes, 2012; Nguon, 2012; Usher \& Kober, 2012; Chowa, Masa, \& Tucker, 2013; Pavalache-Ilie \& Tirdia, 2015; Ubale, Abdullah, Adam, \& Embong, 2016; Park, Stone, \& Holloway, 2017; Amponsah, Milledzi, Ampofo, \& Gyambrah, 2018; Cabus \& Aries, 2017; Gan \& Bilige, 2019). In addition, several studies have found that parental involvement also induces good behaviours such as reducing absenteeism and dropouts, as well as increasing the motivation to learn among 
the students (El Nokali, Bachman, \& Votruba-Dzral, 2010; Hango, 2007; McNeal, 1999; Usher \& Kober, 2012; Chowa et al., 2013; Patel, 2014; Ruholt, Gore, \& Dukes, 2015).

The Malaysian government has recognised the importance of parental involvement as a tool in improving students' performance and quality of education. In the Malaysian Education Blueprint 2013-2025, toolkits to encourage parents' involvement were introduced as a national initiative to help the parents be more engaged in their children's education matters (Ministry of Education Malaysia, 2013). The toolkit for the parents-school relationship is called Sarana Sekolah and the toolkit for parent-children relationship is called Sarana Ibubapa. In Sarana Ibubapa, a survey and guidelines are provided for parents to analyse their own weaknesses and strengths in educating their children focusing on four angles: providing a conducive learning environment at home, allowing social interaction, and giving academic support, and communicating with the children. Additionally, parents are also encouraged to discuss with the Parents-Teachers Association (PTA) and other parents to increase their knowledge on the best parental involvement practices.

The government introduced this initiative due to the concern over the lack of parental involvement among Malaysian parents. According to a report on Malaysian education performance by the World Bank (2013), low parental involvement was one of the key constraints in improving the quality of basic education in this country. Time constraint and inability to properly express their concerns or ideas were among parental involvement deficiency reasons. Patel (2014) found that some parents from lower-income groups were not actively involved in their children's education because they put their total trust in the teachers and school's hands. More than half of the low-income parents were not interested in having more interactions with the school as they think that the school and teachers know their jobs well. Therefore, these parents put their trust wholeheartedly on the teachers and thought that they do not need to intervene in matters related to their children's education, which is translated into lack of parental involvement. The parents also thought that they have been informed well about their children's academic performance. Parents from low-income families usually assume that everything is going well with their children's academic performance without knowing much about the actual progress their children make (Patel, 2014). This then led to a mismatch of information between the reality of their children's educational achievement and their assumption.

Patel (2014) also reported low home-based parental involvement where parents rarely involved in the activities to help their children at home. Most parents spared limited amount of time to help with their children's homework 
and revision as most of them could not help their children with homework because of their low education level. This was also highlighted in the Malaysia Education Blueprint 2013-2025 where parents' socioeconomic status was identified as a significant factor affecting children's academic achievement (Ministry of Education, 2016). Khalid (2016) also provided evidence on the importance of parent education background as it is directly related to educational mobility. He found that $33 \%$ of children whose parents have no formal education obtained from tertiary education while the percentage was $92 \%$ among those whose parents have obtained tertiary education.

Another important observation related to parental involvement is the increasing number of dual-earner households, especially in the urban areas. The increasing participation of women in the labor market has contributed to the increasing patterns of dual-earner families. In the field of household studies, this phenomenon has raised the interest on the issue of intra-household allocation of time. In Malaysia, women's role in the economy has received favorable attention. For instance, National Policy on Women was introduced in 1985 and inclusion of the issues of women empowerment in the national plans serves as an indicator to the level of government's commitment towards strengthening women's role in the economy and consequently had been identified as a contributing factor to the increased participation of women in the labor market (Ramli et al., 2013). In the period of 1990 to 2016, women's participation increased from $47.8 \%$ to $54.3 \%$ ("World Bank", 2017). The highest percentage of women involved in the labor market fell within the age group between 24 and 44 years old. This age group coincides with marriage and childbearing period. The greater access and opportunities for women in education have provided a platform for them to participate in the labor market (Ramli et al., 2013). One potential issue that may arise from the increased number of dual-earner households is less time spent by the parents on their children. Nock and Kingston (1988) highlighted in their study that parents in dual-earner families spend less time with children compared to single-earner families. Hofferth and Sandberg (2001) found that maternal employment will lessen mothers' time to interact with their children, such as less time in reading together or helping with homework.

The issue of middle-income squeeze in Malaysia is also worth concerning. In a recent report on the state of Malaysian households, Khalid (2016) provided evidences of middle-class squeeze phenomenon. Comparing parents' income to their first child, Khalid found that children belonged to thirdand fourth-income quantile did not do better than their parents in terms of income. Their income was found to be either at the same level as their parents or decreased. Additionally, Kaur (2016) reported that the recent upsurge in food 
prices has pushed the cost of living up, which has reportedly affected the urban middle income. Thus, Malaysia was urged to formulate appropriate policies to cater for its middle-income group ("World Bank", 2017.) The sluggish educational mobility among the lower income families might later result in persistent social inequality among Malaysians.

In addition, parental involvement in children's education is becoming increasingly important during school lockdowns due to COVID-19 pandemic. Online learning requires readiness and commitment of the students where during remote learning period only parents could provide guidance, monitoring and motivation to the students.

To this end, this study was set to examine the determinants of parental involvement focusing on home-based involvement in the context of Malaysian urban households. The objectives were twofold: first, to explore the level of parental involvement at home among urban parents; and second, to examine the determinants of parental involvement level with particular interest on the role of dual-earner characteristic. This study focused on the level of home-based parental involvement for families with primary school-aged children. This paper is arranged as follows: Section 2 provides a review of the relevant literatures, Section 3 discusses the methodology used, Section 4 presents the results, followed by the discussion in Section 5 and the final section concludes.

\section{Literature Review}

\section{Conceptualisation of Parental Involvement}

The definition of parental involvement varies among researchers. Cotton and Wikelund (1989) defined parental involvement as the participation of parents in their children's education. The United States No Child Left Behind Act (2001) defined parental involvement as "the participation of parents in regular, twoway and meaningful communication involving student academic learning and other school activities, including ensuring that parents play an integral role in assisting their child's learning; that parents are encouraged to be actively involved in their child's education at school; that parents are full partners in their child's education and are included, as appropriate, in decision-making and on advisory committees to assist in the education of their child" (Department of Education United States, 2004). Meanwhile, according to Muller (1995), parental involvement is the interaction between three capitals, namely social, human and financial capitals. Robinson and Harris (2014) suggested that parental involvement includes parents' communication with their children and their cooperation with the teachers and the academic institution, with the objectives to improve the academic performance of their children. Miksic (2015) defined 
parental involvement as the way parents provide psychological and emotional support to their children, such as providing motivation or doing activities together at home and at school. This is apparently in line with the idea that parental involvement refers to being concerned or emotionally connected as suggested by Wingard and Forsberg (2009). In sum, parental involvement can be defined as interactions between parents, children, and school where human, financial, and social capitals are utilised. Parental involvement can be categorised into school-based involvement and home-based involvement. Home-based involvement deals with parents' interaction with their children where education is concerned while school-based involvement concerns parents and school relationships. In this study, the focus was given to home-based involvement.

\section{Determinants of Parental Involvement}

Previous studies advocated the importance of parental involvement in children education and it is most crucial for children from low-income families (Cotton \& Wikelund, 1989). It has the potential to offset the effect of constrained economic resources in an economically disadvantaged family so that the children could enjoy the same benefit of education as the well-off (Hango, 2007). Despite the said benefit of parental involvement for lower-income group, a large number of literature found that parents from lower socioeconomic status involved less in children education (Epstein \& Becker, 1982; Astone \& McLanahan, 1991; Balli, Demo, \& Wedman, 1998; Fantuzzo, Tighe, \& Childs, 2000; McLanahan, 2004; Green, Walker, Hoover-Dempsey, \& Sandler, 2007; Ji \& Koblinsky, 2009; Majzub \& Salim, 2011; Stylianides \& Stylianides, 2011; Ho \& Willms, 1996; Usher \& Kober, 2012; Vellymalay, 2012; Oswald, Zaidi, Cheatham, \& Brody, 2018; Cashman, Sabates, \& Alcott, 2021). Socioeconomic status is an important indicator when examining the level of parental involvement. Family background could include financial capital (income), human capital (parents' level of education) and social capital (the interactions between parents and children).

Parents' education level is one of the undeniably important human resources in a family. As mothers are more likely to spend more time with their children, they play a substantial role in the children's intellectual development. Mothers' academic credential was found to be significant in determining the level of parental involvement in children's education (Baker \& Stevenson, 1986; Kohl, Lengua, \& McMahon, 2000; Yulianti, Denessen, \& Droop, 2018; Brossard et al., 2020). Mothers with higher education attainment were found to interact and involve more frequently with their children as compared to low educated mothers (Sayer, Gauthier, \& Furstenberg, 2004). Hapsari, Sugito, and Fauziah (2020) reported that mothers play a greater role during online learning due to 
COVID-19. They further emphasised the importance of mother's education background. Meanwhile, Zick, Bryant, and Österbacka (2001) examined the role of father's education on parental involvement and found positive result in which the more educated the father, the higher the frequency of both parents playing with their child and doing activities together. They suggested that more educated parents will try to dedicate their time with their children. This is further supported by Lee and Bowen (2006) who found that parental involvement was much higher for parents with 2-year college degrees and above, particularly in parent-child discussions at home and school involvement. These parents also placed higher expectation on their children to succeed academically.

Differences in parental involvement could also be derived from differences in the characteristics of the households. A study by Astone and McLanahan (1991) and Oswald et al. (2018) showed that parental involvement depends on the parents' marital status. They reported a significantly lower involvement of those from single-parent households. Meanwhile, Kohl et al. (2000) suggested that single parents will be more likely to have a direct involvement with their child at home rather than involve in school activities due to time constraint. Parents' age and family size could also provide the explanation for the variation in parental involvement level. A study by Amato and Rivera (1999) found a negative relationship between parents' age and parental involvement in which older parents involved less. Stylianides and Stylianides (2011) reported that children from higher socioeconomic status and those who were the only child spent less time in childcare centers, suggesting a high level of parental involvement. Cashman et al. (2021) examined the role of wealth in determining parental involvement on low-achieving child and found, unsurprisingly, lower involvement of families facing higher financial constraints.

In the Malaysian context, the study on parental involvement has been rather active with mixed findings. Looking into home-based involvement, Vellymalay (2012, 2013a, 2013b) reported different findings between Indian and Malay families when looking into the role of socioeconomic characteristics in determining level of home-based parental involvement. Among Indian families, education, income and employment status explained the variation in the level of parental involvement while none of those characteristics matters for Malay families. Vellymalay (2013b) attributed the contradictory findings that his respondents were students of a highly performed school and thus parents were aware of the importance of their children's education regardless of their socioeconomic status. He also found that other than socioeconomic status, characteristics of the household contributed to the level of involvement. In particular, he looked at the impact of household size on level of commitment and 
found that larger households often involved less in matters related to their children's education (Vellymalay, 2013a).

Meanwhile, Abd. Hamid, Othman, Ahmad, and Ismail (2011), Zakaria and Mohd. Salleh (2011), Syed Hassan, Mansor, and Hashim (2015), Ab. Latif and Abdullah (2016), Ngu, Hanafi, and Taliskhan (2016), and Yusoff and Azman (2018) studied the impact of parental involvement on students' academic achievement. Most studies reported significant contributions of parental involvement on children's education outcome. Abd. Hamid et al. (2011) investigated the impact of parental involvement on academic achievement among children from poor households where they found significant relationships between all elements of involvement to students' achievement even though the levels of involvement were reported to be between moderate and low. Parental involvement was measured using Inventory of Parental Influence, which covers three elements: discussion, care and communication. Yusoff and Azman (2018)'s findings indicated importance of parental support in determining students' work achievement via students' participation in schools or academic activities. Two constructs represent parental support; both related to parental concern over school activities and motivation to study hard at school. Zakaria and Mohd also reported a significant contribution of parental involvement. Salleh (2011), Syed Hassan et al. (2015) and Ngu et al. (2016).

In contrast, Mahamud, Che Hassan, and Mohd. Fakhruddin (2018) evaluated the achievement of Sarana Ibubapa by looking at home-based parental involvement, communication and support for children education. The selfreported score of involvement in children's education matters was high while communication and support were moderate among the selected parents. Although the parents reported high involvement, the authors, however, found no relationship between the parental involvement and their children's academic achievement.

Various reasons explained low involvement among parents, especially those belonging to lower socioeconomic status. The important constraint facing these parents is time (Epstein \& Becker, 1982; Lareau, 1987; Thomson, Hanson, \& McLanahan, 1994; Stylianides \& Stylianide, 2011; Usher \& Kober, 2012). Cabus and Aries (2017), on the other hand, found that parental involvement differs according to the order of birth, which is higher for earlier children. Socioeconomically disadvantaged parents are mostly from working class and would not have much time to spare for their children. Lack of financial resource also plays a key role in explaining the lower involvement of parents from lower socioeconomic group (Thomson et al., 1994; Cashman et al., 2021), which restricted the ability of the parents to provide favorable home environment for 
the children (Usher \& Kober, 2012). Cashman, Batthacarjhea, and Sabates, (2020)'s study on parental involvement during lockdowns found that more affluent families have better resources to be involved in their children's education at home.

Some other studies highlighted lack of human capital such as skills to educate the children (Lareau, 1987), lack of confidence (Cotton \& Wikelund, 1989) and an unclear prospect of the roles that they can play in their children's education (Usher \& Kober, 2012) as barriers to parental involvement among these parents. Sometimes, parents were reluctant to get involved due to low selfesteem of feeling unwelcome at schools (Cotton \& Wikelund 1989). Ruholt et al. (2015) proposed that parenting style that was shaped by parents' backgrounds and experiences during childhood as the explanation for the low involvement. Ji and Koblinsky (2009) found that communication and language as the barriers to parental involvement among low-income Chinese immigrants. Although these parents have high aspirations and expectations for their children to succeed, language barriers and time constraints have made it difficult for them to get involved in their children's education. Barriers in the form of lacking human capital were magnified during the pandemic when parents had to assume different roles during the remote learning period (Garbe, Ogurlu, Logan, \& Cook, 2020; Koskela, Pihlainen, Piispa-Hakala, Vornanen, \& Hamalainen, 2020), and most of them were unprepared for the shift of responsibilities due to lack of knowledge or pedagogy (Garbe et al., 2020).

\section{Parental Involvement among Dual-earner Households}

The increased participation of women in labor market subsequently led to the rise in proportion of dual-income earner households, which brought change to the maternal and paternal roles in a household. Past researches that delved into examining the effects of dual-earner characteristics of a household on parental involvement have mostly agreed that parents in dual-earner families spent less time with their children compared to single-earner households (Nock \& Kingston, 1988; Hewlett, 1991; Suppal \& Roopnarine, 1999; Hofferth \& Sandberg, 2001). However, there were a few studies that reported contrasting findings, such as Bianchi (2000) and Zick et al. (2001). Bianchi (2000) reported that the level of involvement was not different between single and dual-earner households due to increasing awareness among parents on education's importance. Moreover, dualearner families had better financial resources and were willing to spend the available time to help their children to succeed in education. Zick et al. (2001) reported that parents in dual-earner households spent more time with their children in reading and helping with homework compared to parents in single- 
earner families. They suggested that although working mothers in dual-earner families might have less time to spend with their children, but they optimised the available time and used it productively on activities that provided most benefit to the children.

Muller (1995) proposed that mothers' employment status as a determinant of parental involvement levels in dual-earner families in which parttime working and educated mothers were found to have the highest level of involvement with their child because they have the ability to balance the time between working and child-care. Correspondingly, Manhas (2013) found that parental education in dual-earner families had a positive correlation with parental involvement level. She suggested that mothers still had higher involvement with their children despite working as they tried to allocate their time to participate in children's activities. A study by Gleditsch and Pedersen (2017) found that parents in dual-earner families tend to involve more in motivating their children by giving praises and affection and involving less in disciplining them. The rise in dual-earner families led to an increasing role of fathers in their children's education. Bianchi (2000) suggested that fathers are more involved with their children in modern dual-earner families than traditional single-earner families. Furthermore, Zick et al. (2001) found that fathers' involvement in helping children doing homework and reading was higher in dual-earner households. Craig and Churchill (2020) examined dualearner households' work and care during COVID-19 and found that lockdowns had resulted in lower paid work, particularly among mothers and increased childcare among fathers with reported reduction in satisfaction over work-life balance.

\section{Materials and Methods}

The analyses performed in this paper were based on primary data collected through a survey conducted in 2015 on households with primary school-aged children. The reasons to focus on households with primary school-aged children are two-fold. Firstly, we wanted to ensure households' homogeneity as primary education is compulsory education years in Malaysia. As much as 2000 questionnaires were distributed in Klang Valley areas, 1150 were returned and only 744 responses were considered for analysis after eliminating the missing values. Nine items were forming the home-based involvement; the items are presented in Table 1 and are ranked based on their mean scores. The respondents were required to indicate each listed item's frequencies based on 5 Likert scales ranging from 1 - never to 5 - often. The Cronbach's Alpha for parental 
involvement construct was 0.862, suggesting an internal consistency of the items to be used as parental involvement measures.

Table 1: Items of Parents' Home-based Involvement

\begin{tabular}{clc}
\hline No. & \multicolumn{1}{c}{ Statement } & Mean score \\
\hline 1 & Motivate the children to study hard & 4.41 \\
2 & Provide the necessary facilities and equipment & 4.23 \\
3 & Obtain feedback from teachers regarding children's & 4.22 \\
& academic achievement & 4.10 \\
4 & Discuss with children regarding their interest & 4.09 \\
5 & Assist children with their homework & 4.01 \\
6 & Discuss with children on education planning & 4.00 \\
7 & Take part in religious activities with children & 3.89 \\
8 & Reading together & 3.63 \\
9 & Take children to participate in community activities & \\
\hline
\end{tabular}

Source: The authors.

To identify the factors influencing home-based involvement among urban households in Klang Valley, the following model served as our baseline model:

Home-based involvement $=f$ (Gender, Marital status, Age, Dual-income household, Income level, Occupation, Mother's education level, Ethnicity)

Home-based involvement was measured by the sum of score of nine Likert items as listed in Table 1. A higher score indicates a higher level of involvement. The average score was 36.569 (maximum possible score is 45), suggesting that on average urban parents reported high involvement in their children's education matters. Table 2 presents the description of the explanatory variables included in the model. The model was estimated using ordinary least square technique (OLS).

Table 2: Description of Independent Variables

\begin{tabular}{llc}
\hline \multicolumn{1}{c}{ Variable } & \multicolumn{1}{c}{ Description } & Expected sign \\
\hline Gender & Male; female (reference group) & + \\
Marital status & Married (reference group); single & - \\
& parent; guardian & - \\
Age & Continuous variable & - \\
\hline
\end{tabular}




\begin{tabular}{|c|c|c|}
\hline $\begin{array}{l}\text { Dual-income } \\
\text { earner }\end{array}$ & 1 = yes; 0 otherwise & - \\
\hline Income level & $\begin{array}{l}\text { RM4000 or less (reference group); } \\
\text { RM4001 - RM9000; more than RM9000 }\end{array}$ & + \\
\hline Occupation & $\begin{array}{l}\text { Government (reference group); private; } \\
\text { self-employed; others }\end{array}$ & ? \\
\hline $\begin{array}{l}\text { Mother's } \\
\text { education level }\end{array}$ & $\begin{array}{l}\text { Degree (reference group); } \\
\text { diploma/certificate; secondary school; } \\
\text { lower than secondary school }\end{array}$ & - \\
\hline Ethnic & $\begin{array}{l}\text { Malay (reference group); Chinese; } \\
\text { Indian }\end{array}$ & ? \\
\hline
\end{tabular}

Source: The authors.

\section{Findings and Analysis}

Table 3 presents the socio-demographic characteristics of the respondents. Households involved in this study were predominantly male-headed. The large percentage of male-headed households was in line with the fact that they were mostly married parents, which made 93.3 percent of the total respondents. The percentage of the households defined as dual-income earner households was 64.9 percent. Dual-income and powered couples (both parents are highly educated) are common characteristics of urban households.

The home-based involvement score was regressed against the sociodemographic characteristics as specified in the estimation model. Table 4 presents the results of the econometric estimation. Collinearity statistics of Tolerance and VIF did not suggest any problem of multicollinearity for our baseline model. We excluded the household heads' education from the regression because it was highly correlated with mother's education due to the aforementioned powered-couple phenomenon. Furthermore, the inclusion of household heads' education level did not contribute to a significant increase in the model's overall fitness. In Model 2 we estimated the same model with additional interaction terms between dual-income characteristics and household income levels. The F-statistics indicates the models were significant $(p<0.05)$, suggesting their usefulness in explaining home-based parental involvement in children's education. 
Table 3: Socio-demographic Characteristics of the Respondents

\begin{tabular}{|c|c|c|c|c|c|}
\hline Characteristic & Frequency & $\%$ & Characteristic & Frequency & $\%$ \\
\hline $\begin{array}{l}\text { Household head's } \\
\text { gender }\end{array}$ & & & $\begin{array}{l}\text { Household } \\
\text { head's } \\
\text { occupation }\end{array}$ & & \\
\hline Male & 635 & 85.3 & Government & 336 & 45.2 \\
\hline Female & 109 & 14.7 & $\begin{array}{l}\text { Private } \\
\text { Self- } \\
\text { employed }\end{array}$ & 288 & 14.7 \\
\hline $\begin{array}{c}\text { Marital status } \\
\text { Married }\end{array}$ & 694 & 93.3 & Others & 11 & 1.5 \\
\hline Single parent & 39 & 5.2 & $\begin{array}{l}\text { Household } \\
\text { income }\end{array}$ & & \\
\hline \multirow[t]{2}{*}{ Guardian } & 11 & 1.5 & $\begin{array}{l}\text { RM4000 and } \\
\text { below }\end{array}$ & 194 & 26.1 \\
\hline & & & $\begin{array}{l}\text { RM4001 - } \\
9000\end{array}$ & 337 & 45.3 \\
\hline Ethnic & & & $\begin{array}{l}\text { More than } \\
\text { RM9000 }\end{array}$ & 213 & 28.6 \\
\hline Malay & 632 & 84.9 & & & \\
\hline Chinese & 70 & 9.4 & & & \\
\hline \multirow[t]{2}{*}{ Indian } & 42 & 5.6 & $\begin{array}{l}\text { Dual income } \\
\text { earner }\end{array}$ & & \\
\hline & & & No & 261 & 35.1 \\
\hline Mother's education & & & Yes & 483 & 64.9 \\
\hline Degree & 332 & 44.6 & & & \\
\hline Diploma/certificate & 212 & 28.5 & & & \\
\hline Secondary school & 188 & 25.3 & & & \\
\hline $\begin{array}{l}\text { Lower than } \\
\text { secondary school }\end{array}$ & 12 & 1.6 & & & \\
\hline
\end{tabular}

Source: The authors. 
Table 4: Determinants of Parental Home-based Involvement

\begin{tabular}{|c|c|c|}
\hline Explanatory variables & Model 1 & Model 2 \\
\hline Household head's gender & $1.106(.000)^{*}$ & $.051(.941)$ \\
\hline \multicolumn{3}{|l|}{ Marital status } \\
\hline Single parent & $-2.552(.024)^{*}$ & $-2.621(.020)^{*}$ \\
\hline Guardian & $-5.561(.002)^{*}$ & $-5.038(.006)^{*}$ \\
\hline Age & $-.099(.001)^{*}$ & $-.095(.002)^{*}$ \\
\hline \multicolumn{3}{|l|}{ Dual-income earner } \\
\hline \multicolumn{3}{|l|}{ Income } \\
\hline RM4001 - RM9000 & $1.146(.060)^{*}$ & $2.594(.001)^{*}$ \\
\hline More than RM9000 & $1.652(.023)^{*}$ & $.791(.626)$ \\
\hline \multicolumn{3}{|l|}{ Household head's occupation } \\
\hline Private & $-.161(.729)$ & $.043(.928)$ \\
\hline Self-employed & $.666(.301)$ & $.660(.304)$ \\
\hline Others & $1.435(.409)$ & $1.947(.263)$ \\
\hline \multicolumn{3}{|l|}{ Mother's education level } \\
\hline Diploma & $-.518(.292)$ & $-.593(.230)$ \\
\hline Secondary school & $-.893(.154)$ & $-.837(.181)$ \\
\hline Others & $-5.083(.003)^{*}$ & $-4.689(.006)^{*}$ \\
\hline \multicolumn{3}{|l|}{ Ethnic } \\
\hline Chinese & $-.412(.570)$ & $-.466(.520)$ \\
\hline Indian & $1.304(.137)$ & $1.141(.193)$ \\
\hline \multicolumn{3}{|l|}{ Dual-income $x$ Income level } \\
\hline Dual x RM4001 - RM9000 & & $-2.778(.009)^{*}$ \\
\hline $\begin{array}{l}\text { Dual x More than } \\
\text { RM9000 }\end{array}$ & & $.044(.980)$ \\
\hline Constant & $41.227(.000)^{*}$ & $40.285(.000)^{*}$ \\
\hline Adjusted R-squared & .053 & .060 \\
\hline F-statistics & $3.747(.000)^{*}$ & $3.810(.000)^{*}$ \\
\hline
\end{tabular}

Note: $\mathrm{p}$-value is in the parenthesis

${ }^{*} \mathrm{p}<0.05$

Source: The authors.

The second column reports the estimation of the baseline model. Household heads' gender, age, marital status and household income were found to be significant $(\mathrm{p}<0.005)$ and in line with prior expectations. Gender of the 
household heads took a positive coefficient indicating that male-headed households' involvement was significantly better compared to female-headed households'. Marital status was also a significant predictor; households with married parents had higher involvement as compared to single parents and guardians. Age entered negatively and as it took a continuous value, the coefficient suggested that the level of involvement decreased with age. The estimation also revealed a significant variation in parental involvement between dual-earner and single-earner families. Nonetheless, mother's education does not play an important role in explaining the variation in parental involvement, except for mothers informal or no formal education categorised as "others".

The estimation in the second column considered the interaction between dual-earner characteristics and income of the households. Overall fitness of the model slightly improved $\left(\mathrm{R}^{2}=0.60\right)$. Predictors from the baseline model remained significant except for gender of the household heads and dual-earner characteristics. The interaction terms recorded a negative and significant coefficient for middle income families $(p<0.05)$, while coefficient for the interaction between dual-earner and high income families turned to be insignificant.

\section{Discussion}

The regression results revealed that household heads' age and gender are important determinants of parental involvement in children's education. Households headed by males and younger parents had a significantly higher involvement score as compared to their respective counterparts. This reflects the possibilities that older parents are struggling to keep up with the ever-changing school syllabus besides the possibilities that younger parents are more exposed to parental education which was found to be a determinant for parental investment in terms of time spent with children. In contrast to previous studies that claimed mother's education level as important determinants for parental involvement (Baker \& Stevenson, 1986; Kohl et al., 2000; Sayer et al., 2004), our estimation results suggested no statistical difference in the level of involvement between mothers who are degree holders and those with diploma or secondary school qualification. The only exception was mothers with less than secondary education were significantly less involved as compared to mothers with a university degree. Higher involvement was also recorded for married parents compared to single parents.

Our focus variable, the dual-earner, was negatively related to parental involvement. Households with working parents had lesser level of involvement, in agreement to findings by Nock and Kingston (1988), Hewlett (1991), Suppal 
and Roopnarine (1999), and Hofferth and Sandberg (2001). The descriptive statistics showed that a larger proportion of urban households was dual-income earner households. If we considered only married couples, eliminating single parents and guardians, out of 694 married couples, 480 (69.2 percent) were dualincome earners. To understand this negative relationship, we cross tabulated the dual-income factor with each home-based involvement item and found that the lowest involvements among dual-income earner households were recorded for spending time reading together, taking part in religious activities and getting feedback from teachers regarding their children's academic performance. Indirectly, this observation suggested that parents in dual-earner families are facing a binding time constraint as those activities require time. This then led to an important concern: as the dual-earner parents in our study spent less time reading together, as well as getting feedback on their children's performance, lack of parental involvement among these families could have a significant effect on children's academic achievement as having high expectations, developing and maintaining communication with the children about their school activities and school work, including developing reading habits are key types of parental involvement (Castro et al., 2015).

The negative effects of dual-earner households on involvement could be moderated by the higher household income earned by dual-earner families, as previous research had devoted the insignificant difference between dual- and single-earner households to the fact that the former have better financial resources (Bianchi, 2000). Furthermore, our baseline model results indicated that families with a higher household income were significantly more involved. Both coefficients for medium- and high-income groups were statistically significant with the magnitude of the difference was found to be higher as the higher the income was. This finding is similar to Vellymalay's (2012) study on Indian families which found a positive relationship between income and parental involvement at home. A simple cross-tabulation revealed that majority of medium $(63.8 \%)$ and higher $(93.9 \%)$ income households were dual-earners while families belonged to the lower-income group were largely single-income earners. In other words, while higher-income allows the parents to involve more at home, it is an offset by the fact that they have lesser time to spend with their children. In fact, when we examined the relationship between income and each item of parental involvements, we found some offsetting effects between dual-income characteristics and income levels where higher-income families involved more in reading together, taking part in religious activities, and getting feedback from teachers regarding their children's performance. On the other hand, items of dual-earner parents performed poorer. Moreover, there were additional elements 
in which higher income households performed better, namely in helping with homework, discussing education planning, and preparing necessary facilities and equipment. Hence, higher income parents have greater advantages in getting involved with the children relative to dual-earners either in terms of activities that require time or require financial resources.

To know the extent to which income offsets the negative effects from dual-earner characteristics, we have added the interaction terms between income groups and dual-earner characteristics. The resulted estimation of including the interaction terms is reported in the third column of Table 4. A negative coefficient was recorded for dual-earner - middle-income interaction, while the higher-income group's coefficient was insignificant. Even though higher-income families were involved more in their children's education, but if both parents were working, their commitment level was not different from those of lower income. We read this finding as a full offsetting effect of a dual-earner factor for higher income households. On the contrary, for middle-income families with working parents, the involvement was predicted to be lower than those of low income, which means the lower involvement due to dual-earner characteristic was not fully compensated by the larger income that these households earned. This observation could contribute to the raising concern over middle-income squeeze issue in Malaysia. Although there is no evidence that we could provide on the effect of lower parental involvement among dual-earner families from middle income group on the children's performance and consequently on their labor market outcome, however this finding could echo Khalid (2016)'s, even though his study is of a long-term observation. As parents belonging to this category showed less involvement, this could affect the children's academic performance and thus the labor market outcome could consequently push the children down the socioeconomic ladder.

\section{Conclusions and Recommendations}

This research aimed at examining the factors affecting parental involvement in children's education among urban households in Malaysia. Based on the data collected from 744 households with primary school-aged children, we found that the most important home-based parental involvement elements are motivation and communication with children. Compared to activities that require financial resources, lower mean scores were reported for elements involving activities that require time, such as reading together and taking part in community or religious activities. The estimation results revealed that the level of parental involvement is determined by the socioeconomic status of the households and the households' heads. In particular, we highlighted the adverse impacts of dual-earner 
characteristics and income levels on parental involvement which we found interesting and has not yet been explored so far, particularly in the case of Malaysia. This may likely happen as the parents need to work extra hours or take second job to cope with the increasing living costs, especially for those living in urban settings where the cost of living is much higher and, therefore, limiting their quality time with the children.

Although our study was done before the pandemic, the study might shed some lights into parental involvement and academic performance during the lockdown. Lost in income might negatively affect the parents' involvement in their children's education, especially in providing physical support for online learning. However, it might increase the parents' ability, especially mothers' to provide more time to oversee their children's education. Furthermore, past studies related to learning during COVID-19 support an increase in maternal involvement, highlighting the importance of mother's education in parental involvement in children's education. On the other hand, if the lockdown did not free up the parents' time to increase their involvement in their children's learning process, like those who are providing essential services, the movement control order could adversely affect the children's academic performance. This is especially true given the fact that during lockdown, teachers' role is limited to distance online teaching. All other monitoring roles are delegated to parents at home. With the absence of parents' involvement, children's academic performance will be affected. Nonetheless, we have to acknowledge that the forms of involvement might be different during the movement control order period as compared to the normal period. School closure and remote learning period due to COVID-19 should place the parental involvement at the center stage. The pandemic has forced parents, especially mothers, to play a greater role in their children's education, highlighting the importance of student-centered learning and nurturing independent learning among the children.

Several research limitations are worth to be highlighted in terms of parental involvement. The actual hours spent on children's educational matter, as well as the actual frequencies of the activities in stipulated time period. Future research could consider collecting actual data in terms of number of hours and frequency of activities to enhance the findings. Future research may also want to examine the long-term effects of low parental involvement, especially on the children's labor market outcomes. Above all, parental involvement measurements are still debatable among the scholars of whether tangible involvement or intangible involvement is more important, which are worth exploring in the context of Malaysian families. 


\section{Acknowledgements}

The authors would like to acknowledge the financial support provided by the University of Malaya under the Equitable Society Research Cluster (ESRC) research grant (project number: RP018C-14SBS).

\section{References}

Ab. Latif, A., \& Abdullah, N. (2016). Penilaian keberkesanan program Sarana Ibu bapa dalam meningkatkan pencapaian murid dalam mata pelajaran Sains sekolah rendah dengan menggunakan Model Penilaian CIPP [Assessment of the Sarana Ibu bapa program in increasing students' achievement in Science subject using CIPP Assessment Model). JPBU Edisi Khas, 87-96.

Abd. Hamid, Z., Othman, J., Ahmad, A. \& Ismail, I.A. (2011). Hubungan antara penglibatan ibubapa dan pencapaian akademik pelakar miskin di negeri Selangor (Relationship between parental involvement and academic achievement of poor students in Selangor). Journal of Islamic and Arabic Education, 3(2), 31-40.

Aghion, P., Boustan, L, Hoxby, C., \& Vandenbussche, J. (2009). The causal effect of education on economic growth: evidence from the United States. Scholars at Harvard. Retrieved from:

https://scholar.harvard.edu/files/aghion/files/causal_impact_of_educatio n.pdf?m=1360041602

Amato, P. R., \& Rivera, F. (1999). Paternal involvement and children's behavior problems. Journal of Marriage and the Family, 6(2), 375-384.

Amponsah, M. O., Milledzi, E. Y., Ampofo, E. T., \& Gyambrah, M. (2018). Relationship between parental involvement and academic performance of senior high school students: The case of Ashanti Mampong Municipality of Ghana. American Journal of Educational Research, 6(1), 1-18.

Asteriou, D., \& Agiomirgianakis, G. M. (2001). Human capital and economic growth time series evidence from Greece. Journal of Policy Modeling, 23, 481-489.

Astone, N. M., \& McLanahan, S. S. (1991). Family structure, parental practices and high school completion. American Sociological Review, 56(3), 309-320.

Baker, D. P., \& Stevenson, D. L. (1986). Mothers' strategies for children's school achievement: managing the transition to high school. Sociology of Education, 59(3), 156-166. 
Balli, S. J., Demo, D. H., \& Wedman, J. E. (1998). Family involvement with children's homework: An intervention in the middle grades. Family Relations, 47, 149-157.

Barro, R. J. (2013). Education and economic growth. Annals of Economics and Finance, 14(2), 301-328.

Bianchi, S. M. (2000). Maternal employment and time with children: Dramatic change or surprising continuity? Demography, 37(4), 401-414.

Brossard, M., Cardoso, M., Kamei, A., Mishra, S., Mizunoya, S., \& Reuge, N. (2020). Parental engagement in children's learning. Innocenti Research Brief, 9. Retrieved from https://www.unicefirc.org/publications/pdf/IRB\%202020-09\%20CL.pdf

Cabus, S. J., \& Aries, R. J. (2017). What do parents teach their children? The effects of parental involvement on student performance in Dutch compulsory education. Educational Review, 69(3), 285-302.

Cashman, L., Bhattacharjea, S., \& Sabataes, R. (2020). Parental perceptions and parental involvement in children's education in rural India: lessons for the current COVID-19 crisis. PAL Network. Retrieved from: https://palnetwork.org/parental-perceptions-and-parentalinvolvement-in-childrens-education-in-rural-india-lessons-for-thecurrent-covid-19-crisis/

Cashman, L., Sabates, R., \& Alcott, B. (2021). Parental involvement in lowachieving children's learning: the role of household wealth in rural India. International Journal of Educational Research, 105.

Castro, M., Exposito-Casas, E., Lopez-Martin, E., Lizasoain, L., Navarro-Asencio, E., \& Giviria, J. L. (2015). Parental involvement on student academic achievement: A meta-analysis. Education Research Review, 14, 33-46.

Chowa, G. A. N., Masa, R. D., \& Tucker, J. (2013). The effects of parental involvement on academic performance of Ghanaian youth: Testing measurement and relationship using structural equation modeling. Children and Youth Services Review, 35, 2020-2030.

Cotton, K., \& Wikelund, K. R. (1989). Parent involvement in education. School Improvement Research Series, SIRS Close-up No. 6, Northwest Regional Educational Laboratory, Portland. Retrieved from https://educationnorthwest.org/sites/default/files/resources/parentinvolvement-in-education-508.pdf

Craig, L., \& Churchill, B. (2020). Dual-earner parent couples' work and care during COVID-19. Gender and Work Organization. https://doi.org/10.1111/gwao.12497 
Department of Education, United States. (2004). Parental involvement guidance. Washington DC: Department of Education USA

Dickens, W. T., Sawhill, I. V., \& Tebbs, J. (2006). The effects of investing in early education on economic growth. Washington, DC: Brookings Institution.

El Nokali, N. E., Bachman, H. J., \& Votruba-Drzal, E. (2010). Parent involvement and children's academic and social development in elementary school. Child Development, 81(3), 988-1005.

Epstein, J. L., \& Becker, H. J. (1982). Parent involvement: a survey of teacher practices. The Elementary School Journal, 83(2), 85-102.

Fantuzzo, J., Tighe, E., \& Childs, S. (2000). Family involvement questionnaire: A multivariate assessment of family participation in early childhood education. Journal of Educational Psychology, 92(2), 367-376.

Gan, Y., \& Bilige, S. (2019). Parental involvement in home-based education and children's academic achievement in China. Social Behavior and Personality: An International Journal, 47(12), e8491.

Garbe, A., Ogurlu, U., Logan, N., \& Cook, P. (2020). COVID-19 and remote learning: experiences of parents with children during the pandemic. American Journal of Qualitative Research, 4(3), 45-65.

Gleditsch, R. F., \& Pedersen, D. E. (2017). Mothers' and fathers' ratings of parental involvement: Views of married dual-earners with preschool-age children. Marriage $\quad \mathcal{E} \quad$ Family Review, 53(6), 589-612. https://doi.org/10.1080/01494929.2017.1283383

Green, C. L., Walker, J. M., Hoover-Dempsey, K. V., \& Sandler, H. M. (2007). Parents' motivations for involvement in children's education: an empirical test of a theoretical model of parental involvement. Journal of Educational Psychology, 99(3), 532-544.

Hango, D. (2007). Parental investment in childhood and educational qualifications: Can greater parental involvement mediate the effects of socioeconomic disadvantage? Social Science Research, 36(4), 1371-1390.

Hanushek, E. A., Woessman, L., Jamison, E. A., \& Jamison, D. T. (2008). Education and economic growth. Education Next, 8(2), 62-70.

Hapsari, S. M., Sugito, \& Fauziah, P. Y. (2020). Parent's involvement in early childhood education during the COVID-19 pandemic period. Jurnal Pendidikan Progresif, 10(2), 162-172.

Hewlett, S. A. (1991). When the bough breaks-The cost of neglecting our children. New York: Basic Books.

Hill, N. E., Castellino, D. R., Lansford, J. E., Nowlin, P., Dodge, K. A., Bates, J. E., \& Pettit, G. S. (2004). Parent academic involvement as related to school 
behavior, achievement, and aspirations: Demographic variations across adolescence. Child Development, 75(5), 1491-1509.

Ho, S. C. E., \& Willms, J. D. (1996). Effects of parental involvement on eighthgrade achievement. Sociology of Education, 69(2), 126-141.

Hofferth, S. L., \& Sandberg, J. F. (2001). Changes in American children's time, 1981-1997. Advances in Life Course Research, 6, 193-229.

International Institute for Applied Systems Analysis (IIASA). (2008). Economic growth in developing countries: Education proves key. IIASA Policy Brief No. 3.

Jeynes, W. (2012). A meta-analysis of the efficacy of different types of parental involvement programs for urban students. Urban Education, 47(4), 706742.

Ji, C .S., \& Koblinsky, S. A. (2009). Parent involvement in children's education: an exploratory study of urban, Chinese immigrant families. Urban Education, 44(6), 687-709.

Kaur, M. (2016). Urban middle class now 40\% poorer. Free Malaysia Today. Retrieved from https://www.freemalaysiatoday.com/category/nation/2016/12/27/urbamiddle-class-now-40-poorer/

Khalid, M. A. (2016). Climbing the ladder: Socio-economic mobility in Malaysia. Working Paper 1/16. Kuala Lumpur: Khazanah Research Institute.

Kohl, G. O., Lengua, L. J., \& McMahon, R. J. (2000). Parent involvement in school conceptualising multiple dimensions and their relations with family and demographic risk factors. Journal of School Psychology, 38(6), 501-523.

Koskela, T., Pihlainen, K., Piispa-Hakala, S., Vornanen, R., \& Hamalainen, J. (2020). Parents' views on family resiliency in sustainable remote learning during the COVID-19 outbreak in Finland. Sustainability, 12, 884. DOI: $10.3390 /$ su12218844

Lareau, A. (1987). Social class differences in family-school relationships: The importance of cultural capital. Sociology of Education, 60(2), 73-85.

Lee, J. S., \& Bowen, N.K. (2006). Parent involvement, cultural capital, and the achievement gap among elementary school children. American Educational Research Journal, 43(2), 193-218.

Liao, L., Du, M., Wang, B., \& Yu, Y. (2019). The impact of education investment on sustainable economic growth in Guangdong, China. A cointegration and causality analysis. Sustainability, 11, 766. https://doi.org/10.3390/su11030766

Lin, T. C. (2003). Education, technical progress, and economic growth: The case of Taiwan. Economics of Education Review, 22, 213-220. 
Lin, T.C. (2004). The role of higher education in economic development: An empirical study of Taiwan case. Journal of Asian Economics, 15, 355-371.

Mahamud, I. Y., Che Hassan, N., \& Mohd. Fakhruddin, F. (2018). Penglibatan ibu bapa dalam aktiviti pembelajaran anak di rumah dan hubungannya dengan pencapaian akademik murid sekolah agama bantuan kerajaan (SABK) [Parental involvement in children's learning activities at home and its relationship to academic achievement of students from government sponsored religious schools). e-Jurnal Penyelidikan dan Inovasi, 5(1), 42-62.

Majzub, R. M., \& Salim, E. J. H. (2011). Parental involvement in selected private preschools in Tangerang, Indonesia. Procedia-Social and Behavioral Sciences, 15, 4033-4039.

Malecki, C. K., \& Demaray, M. K. (2006). Social support as a buffer in the relationship between socioeconomic status and academic performance. School Psychology Quarterly, 21(4), 375-395.

Manhas, S. (2013). Work variables as related to parental involvement in dual earner couples with young children. Global Research Analysis, 2(9), 60-63.

McLanahan, S. (2004). Diverging destinies: How children are faring under the second demographic transition. Demography, 41(4), 607-627.

McMahon, W. W. (1998). Education and growth in East Asia. Economics of Education Review, 17(2), 159-172.

McNeal, R. B. (1999). Parental involvement as social capital: Differential effectiveness on science achievement, truancy, and dropping out. Social Forces, 78(1), 117-144.

Miksic, M. Y. (2015). Parent involvement: Theory, practice, and head start. New York: CUNY Institute for Education Policy.

Ministry of Education Malaysia. (2013). Malaysia Education Blueprint 2013-2025. 2013. Putrajaya: Ministry of Education Malaysia.

Muller, C. (1995). Maternal employment, parent involvement, and mathematics achievement among adolescents. Journal of Marriage and the Family, 57(1), 85-100.

Ngu, L. S., Hanafi, Z., \& Taliskhan, M. (2016). Influence of parental involvement on academic achievement. International Journal of Advanced Education and Research, 1(4), 1-4.

Nguon, S. (2012). Parental involvement and students' achievement in Cambodia: Focusing on parental resourcing of public schooling. International Journal of Educational Research, 53, 213-224.

Nock, S. L., \& Kingston, P. W. (1988). Time with children: The impact of couples' work-time commitments. Social Forces, 67(1), 59-85. 
Oswald, D. P., Zaidi, H. B., Cheatham, D. S., \& Brody, K. G. D. (2018). Correlates of parent involvement in student's learning: Examination of a national data set. Journal of Child and Family Studies, 27, 316-323.

Park, S., Stone, S. I., \& Holloway, S. D. (2017). School-based parental involvement as a predictor of achievement and school learning environment: An elementary school-level analysis. Children and Youth Services Review, 82, 195-206.

Patel, T. (2014). Malaysian education: What do the poor really want? A look at education needs and aspirations of the bottom 40 percent of households in Malaysia. Policy Ideas no. 12. Kuala Lumpur: IDEAS Malaysia.

Pavalache-Ilie, M., \& Tirdia, F. A. (2015). Parental involvement and intrinsic motivation with primary school students. Procedia - Social and Behavioral Sciences, 187, 607-612.

Pegkas, P. (2014). The link between educational levels and economic growth: A Neoclassical approach for the case of Greece. International Journal of Applied Economics, 11(2), 38-54.

Petrakis, P. E., \& Stamatakis, D. (2002). Growth and educational levels: a comparative analysis. Economics of Education Review, 21, 513-521.

Robinson, K., \& Harris, A. L. (2014). The broken compass: Parental involvement in children's education. Cambridge, Massachusetts: Harvard University Press.

Ruholt, R. E., Gore, J., \& Dukes, K. (2015). Is parental support or parental involvement more important for adolescents? Undergraduate Journal of Psychology, 28(1), 1-8.

Sayer, L. C., Gauthier, A. H., \& Furstenberg, F. F. (2004). Educational differences in parents' time with children: Cross-national variations. Journal of Marriage and Family, 66(5), 1152-1169.

Self, S., \& Grabowski, R. (2003). Education and long-run development in Japan. Journal of Asian Economics, 14, 565-580.

Self, S., \& Grabowski, R. (2004). Does education at all levels cause growth? India, a case study. Economics of Education Review, 23, 47-55.

Stylianides, A. J., \& Stylianides, G. J. (2011). A type of parental involvement with an isomorphic effect on urban children's mathematics, reading, science, and social studies achievement at kindergarten entry. Urban Education, 46(3), 408-425.

Suppal, P., \& Roopnarine, J. L. (1999). Paternal involvement in child care as a function of maternal employment in nuclear and extended families in India. Sex Roles, 40(9), 731-744. 
Syed Hassan, S. S., Mansor, N., \& Hashim, C. N. (2015, 24 October). Model for parental involvement and children schooling in Malaysia. Paper presented at the IRES $13^{\text {th }}$ International Conference, Seoul, South Korea.

Thomson, E., Hanson, T. L., \& McLanahan, S. S. (1994). Family structure and child well-being: economic resources vs. parental behaviors. Social Forces, 73(1), 221-242.

Ubale, A. Z., Abdullah, A. H., Adam, F., \& Embong, R. (2016). The effects of Epstein's types of parental involvement in learning Islamic education. The Social Sciences, 11(2), 147-155.

Usher, A., \& Kober, N. (2012). What roles do parent involvement, family background, and culture play in student motivation? Center on Education Policy, The George Washington University. Retrieved from: https://files.eric.ed.gov/fulltext/ED532667.pdf

Vellymalay, S. K. N. (2012). Parental involvement at home: Analysing the influence of parents' socioeconomic status. Studies in Sociology of Science, $3(1), 1-6$.

Vellymalay, S. K. N. (2013a). Effects of family size on parental involvement in their children's education. Journal of Human Capital Development, 6(2), 99114.

Vellymalay, S. K. N. (2013b). Relationship between Malay parents 'socioeconomic status and their involvement in their children's education at home. e-BANGI, 8(2), 98-108.

White, K. R. (1982). The relation between socioeconomic status and academic achievement. Psychological Bulletin, 91(3), 461-481.

Wingard, L., \& Forsberg, L. (2009). Parent involvement in children's homework in American and Swedish dual-earner families. Journal of Pragmatics, 41, 1576-1595.

World Bank. (2013). Malaysian economic monitor: High-performing education. Bangkok: World Bank.

World Bank: Malaysia needs to set agenda for middle class, narrow inequalities. (2017, December 6). Free Malaysia Today. Retrieved from: http://www.freemalaysiatoday.com/category/nation/2017/12/06/worldbank-malaysia-needs-to-set-agenda-for-middle-class-narrowinequalities/

Ramli, Z., Md. Sum, S., Selvadurai, S., Lyndon, N., Er, A. C., \& Jamian, M. N. (2013). The history and current status of dual-career families in Malaysia. Asian Social Science, 9(6), 16-21. 
Yulianti, K., Denessen, E., \& Droop, M. (2018). The effects of parental involvement on children's education: A study in elementary school in Indonesia. International Journal about Parents in Education, 10(1), 14-32.

Yusoff, H. M., \& Azman, N. (2018). Pencapaian akademik murid lelaki dan perempuan: peranan sokongan pembelajaran dan keterlibatan murid [Academic achievement of male and female students: the role of learning support and students' involvement). Malaysian Journal of Learning and Instruction, 15(2), 257-287.

Zakaria, A. R., \& Mohd. Salleh, N. (2011). Konteks keluarga dan hubungannya dengan penglibatan ibu bapa dalam pendidikan anak-anak di sekolah menengah. Jurnal Pendidikan Malaysia, 36(1), 35-44.

Zick, C. D., Bryant, W. K., \& Österbacka, E. (2001). Mothers' employment, parental involvement, and the implications for intermediate child outcomes. Social Science Research, 30(1), 25-49. 